\title{
CIVIL DEFENSE, LEADERSHIP AND HEURISTICS FOR THE EDUCATION OF HEADQUARTERS FOR EMERGENCY SITUATIONS
}

\author{
Paun J. Bereša ${ }^{a}$, Kristian P. Bereš ${ }^{b}$, Sreten S. Cvetkovićc \\ ${ }^{a}$ Ministry of Defence of the Republic of Serbia, Department \\ for Military Obligations, Regional Center Novi Sad, MoD centre \\ Zrenjanin, Republic of Serbia, \\ e-mail: paunberes@gmail.com, \\ ORCID iD: (iphttp://orcid.org/0000-0001-7006-9722 \\ ${ }^{\mathrm{b}}$ Intelliview AS, Oslo, Norway, \\ e-mail: kristianberes@gmail.com, \\ ORCID iD: iil http://orcid.org/0000-0002-6732-5788 \\ ${ }^{c}$ Ministry of Defence of the Republic of Serbia, Department for \\ Military Obligations, Regional Center Novi Sad, MoD centre \\ Zrenjanin, Republic of Serbia, \\ e-mail: sreten1970@gmail.com, \\ ORCID iD: (1)http://orcid.org/0000-0002-1119-482X
}

DOI: 10.5937/vojtehg64-8863

FIELD: Education

ARTICLE TYPE: Professional Paper

ARTICLE LANGUAGE: English

Abstract:

This paper presents solving heuristically conceived problems in the Civil Defence by making adequate decisions in an emergency and the state of emergency with a special emphasis on the application of the heuristic model of training emergency teams-headquarters and on the role of a leader as a factor of good leadership. It is intended for command and teaching staff of the Civil Defence: local authorities (mayors of districts, cities and municipalities - commanders) and the system of protection and rescue (the Sector for Emergency Situations). The heuristic approach to problem solving should enable command staff-leaders from the local to the national level to make adequate decisions in emergency situations after the proclamation of emergency and the state of emergency in a territory part or the whole territory of the Republic of Serbia - functioning of the civil defense and the third mission of the Army of Serbia, as well as to point out the necessity of coordination between the local and national level.

Key words: civil defense, leadership, heuristics. 


\section{Introduction}

The modern world (industrial, technological, informational, global) need leaders, trained, ready and able to: use new complex tools; quickly and efficiently acquire, build and implement a variety of knowledge; actively and responsibly participate in complex social and economic relations and processes in everyday life; and make adequate, rational and best decisions, especially in emergency situations and after the declaration of a state of emergency in the territory of the Republic of Serbia.

On the territories of local government units-LGUs (cities, municipalities) there can be an outbreak of all types of emergencies (wars, threat of natural disasters such as floods, fires of larger scales, earthquakes, landslides, etc.) as well as technical accidents i.e. emergencies (identified as 36) (Bereš et al, 2015, p.71) which should be timely detected for the purpose of taking measures to protect and evacuate people and goods.

Timely, accurate and precise information in these situations means life. Therefore, the headquarter staff for emergency situations are given special attention when it comes to their level of training, skills in handling the most modern and versatile equipment, resourcefulness in emergency situations and timely transfer of information to entities responsible for rapid intervention in the above-mentioned situations.

This work was created in the framework of the research primarily aimed at determining the relationship between learning and training emergency situation teams-headquarters after the proclamation of a state of emergency and the performance of leaders in the implementation of protection and rescue measures in these situations.

In such situations, leaders as creators of ideas and as builders of awareness about the necessity of realization of ideas have always had a crucial role in the development of the mankind. Leaders focus their abilities on technical progress, development and meeting the needs of the mankind in general and in emergency situations they focus on protecting and rescuing people, animals, material and cultural goods. These are the values that cannot be questioned, but they must not be realized at the expense of nature, environment and population, which often happened in the past. Today we are witnessing the harsh effects of such attitude of the man towards the natural world, which undoubtedly leaders are largely responsible for. Amidst ecological crises and natural and manmade disasters, when there is still no real solution to the problems in emergency situations, leaders are more often than not required to be change agents in this area. The prerequisite for changing the attitude of the man towards nature and the environment is the existence of environmental awareness and responsibility in all strata of the society in peace and emergencies alike. This work is dedicated to defining factors of environmental 
awareness and responsibility and obligations of leaders to develop and apply a comprehensive policy of improving the ecological awareness and responsibility of all and at all levels in all situations.

\section{Definition of the term}

Civil Defence is a part of a unified defense system, organized for the successful functioning of government bodies, autonomous provinces, local authorities, companies and other legal entities, with the aim of protecting and rescuing citizens, providing conditions for life and work and meeting the needs of defense forces in emergency and war conditions.

Leadership in this case - the state (state leadership) as a base and system integrator of meeting the needs of the society, must take the leadership role in the development of environmental awareness, protection and rescue and responsibility to defend the country through its elected representatives (the president of the state, prime minister, etc.). To fulfill its leadership role, the state transfers its powers to local authorities (mayors of districts, cities and municipalities - commanders of emergency situation headquarters - i.e. leaders from the local to the state level) with the task of motivating the team members and the population in the endangered territory so that preventive measures and protection and rescue measures can be performed with ease and satisfaction, doubts about the future are replaced by belief, disagreements are turned into cooperative work, safety is replaced by self-confidence, and activities are implemented with the necessary quality thus providing high performances of respective organizationslocal authorities units for emergencies from the local to the state level.

Heuristics - "Eureka" is defined as "I found, I discovered". The term "heuristics" means "science of the ways of finding new scientific knowledge" (Hotomski, 1995) and comes from the idea of eureka.

The integrated protection and rescue system establishes a uniform system of management, organizing citizens and logistic support in protection and rescue with an efficient system of information in peace, emergency, state of emergency and state of war (Bereš, Bereš, 2014, pp.152-164).

\section{Leadership and Personality}

In order to explain the relationship between the leadership and the personality, we analyzed the theory and some research in this field in the world and in our country:

1. Determination of leadership in terms of personality relates to the identification of personal characteristics or personality traits of leaders. Studies have shown that there are some features that are desirable for 
every leader because they increase the chances of success; on the other hand, possessing certain qualities is not sufficient for becoming a leader. "Some properties, therefore, increase the likelihood that someone will become a leader, but they are not a guarantee for it" (Petković, et al., 2002). Studying the characteristics of leaders was not in focus for a while, but with transformational and transactional leadership, that approach regained its importance. In recent years, in addition to personality traits, skills and abilities have been studied (they are often treated as one in literature). Here is some research on personality traits in leaders which may be influential in their business success.

According to Bennis (Bennis, 1991), there are a number of competencies which make a leader, but four stand out as the most significant ones. These are:

- Management of meaning, refers to the interpretation of reality to their followers,

- Management of attention, refers to drawing attention to themselves so that they could fullfill the first requirement which concerns personality traits,

- Trust management, refers to the consistency of followers because in this way they gain trust,

- Self-management, refers to the existence of a real image of themselves and their capabilities.

Benis talks about competencies, but the subtext shows that they depend on the personality traits of leaders and their skill to present themselves in the best possible way. Also, this definition is entirely related to the followers, which highlights the view that there is no leadership without followers.

Other authors consider personality traits of leaders as one of possible factors of leadership.The personal characteristics, leadership factors, (Petković, Jovanović, 2002) include:

- Personal values, a system of values and convictions of individuals, which are related to the shaping of perception, problem diagnosis, decision making and personal preferences,

- Propensity to risk refers to mastering reality,

- Skills, ability to influence others to follow them,

- Decision making, refers to speed and effectiveness or informedness and efficiency.

According to Luthans (Luthans, 2005), research distinguished the following features as the most important ones in leaders successful in business:

- Motivation to persevere in achieving the objectives,

- Motivation to lead the people,

- Integrity, which includes the desire for truth and converting words into action, 
- Self-confidence that makes others have confidence in them,

- Intelligence that often consists in the ability of information processing, problem solving and discovery of solutions,

- Knowledge of the business of a particular organization,

- Emotional intelligence.

Kirkpatrick and Locke (Kirkpatrick, Locke, 1991) considered that the combination of characteristics of leaders and other factors contributes to the success of leaders in business. According to them, the most important characteristics of leaders for achieving success are as follows: initiative,

- Energy, as a desire to prove oneself, ambition, perseverance,

- Honesty and integrity, as reliability, trustworthiness, openness,

- Leadership motivation, as a desire for domination in order to achieve common goals,

- Self-confidence, as faith in their own abilities,

- Ability to perceive, as intelligence, the ability to summarize and interprete large quantities of information,

- Knowledge of the business, as knowledge of the entire industry, appropriate technical achievements, and the like.

The leaders' attributes that stood out on the basis of research are:

- Creativity, as in originality,

- Flexibility, as an ability to adapt to the needs of followers and to the demands of the situation.

2. It is interesting to see what kind of reputation today's leaders in Serbia have, how citizens see them, what they think about them and their role in the society. The study, which was conducted in December 2007 (Ajduković, 2007), generally speaking, has shown that citizens do not have a high opinion of today's leaders in Serbia. Although they agree that leadership is necessary, they do not see today's successful people as leaders in the true sense of the word. Even 60 percent of respondents to the question whether there are leaders in our country gave the answer no. In this context, the respondents' answers to the question about the most common qualities of the Serbian leaders were not surprising (Ajduković, 2007, p.22).

The author of the study notes that "leaders typically show, unfortunately - at least the respondents think so - greed, unscrupulousness, the ability of manipulation and avidity. Only $9.2 \%$ of the respondents thought that our leaders have rightousness as a feature, and even fewer (7.1\%) thought they have sincerity" (Ajduković, 2007, p.23). This study suggests that the essence of success is the possession of power, because affiliation to political parties, money or important contacts are some of the sources of power (Table 1). 
Table 1 - Which of the following characteristics usually characterize Serbian leaders? (Ajduković, 2007)

Таблица 1 - Какие наиболее распространенные черты сербских лидеров? (Ajduković, 2007)

Tabela 1 - Koje od navedenih osobina najčešće odlikuju srpske lidere? (Ajduković, 2007)

\begin{tabular}{|l|r|l|l|}
\hline \multicolumn{1}{|c|}{ ANSWER } & $\%$ & \multicolumn{1}{c|}{ ANSWER } & $\%$ \\
\hline Unscrupulousness & 70.3 & Dynamism & 20.5 \\
\hline Moneygrubbing & 69.1 & Diligence & 14.3 \\
\hline The ability to manipulate & 60.2 & Objectivity & 13.3 \\
\hline Greed & 58.2 & Righteousness & 9.2 \\
\hline Forcefulness & 40.3 & Sincerity & 7.1 \\
\hline Intelligence & 38.5 & Competitive spirit & 6.6 \\
\hline Charisma & 30.3 & Some other & 6.5 \\
\hline
\end{tabular}

3. The results of the study on the characteristics of Serbian leaders or leaders in transition are given further on for possible comparisons. Since the sample is specific, a brief overview of the methods and techniques used in the study is given first.

The descriptive and empirical methods were used in this research, a so-called multiple case study. The technique used was the interview. The interview was structured, including a pre-prepared framework for asking questions. Due to the variety of respondents' jobs as well as their different social, political and life experience, the questions were not quite the same for each interviewee, but were tailored to specific situations.

Through a guided interview, data were collected on the education and the development path of the respondents. The development path refers to the work and life biography of the leader. Career information and key life events were obtained through interviews.

The performance of leaders was estimated through a set of leadership characteristics. We nvestigated the personality traits such as intelligence, work energy, vision, charisma, intuition, anxiety, depression and anger, selfesteem, desire for leadership, communication skills, creativity, ambition, persistence, consistency, informedness, and interest in politics.

The study included ten case studies, i.e. an interview was conducted with ten respondents.

For the purpose of interviewing, the questionnaire represented the basic structure and the database of questions based on which the interview was conducted. Depending on the situation, the questions were supplemented, extended, or changed. The questionnaire contains three sections: personal information and education, working biography and personality traits. 
In this study, the sample consisted of ten respondents. Nine of them were male and one was female.

The research results suggest that in Serbia, males are the dominant population from which leaders come. Serbia is still perceived as patriarchal environment in which the role of women is primarily related to the family, and then to professional tasks.

All ideas about leadership are based on people, influences and targets to be achieved. It involves the use of influence to achieve particular targets.

Influence means that interactions between people are governed by the power of authority, position and knowledge.

Hence, the leadership can be understood as the ability to influence employees to strive for the achievement of a particular goal (Nikezić, 2011, pp.202-203). It is a dynamic process that involves the use of power to lead people towards a goal.

Table 2 shows a number of personal characteristics of leaders. A way to approach the key characteristics of a leader is to analyze the autocratic and democratic styles of leadership.The autocratic leader seeks to centralize authority and to make people focus on achieving objectives using legitimate power, reward and punishment. The democratic leader delegates authority to others, encourages participation and relies on expert and reference power. The first studies on these leadership characteristics were performed at the University of lowa by K Levin (Nikezić, 2011, p.203).

Table 2 - Some personal characteristics of leaders (Nikezić, 2011, p.159)

Таблица 2 - Некоторые личностные характеристики лидеров (Nikezić, 2011, p.159)

Tabela 2 - Neke lične karakteristike lidera (Nikezić, 2011, p.159)

\begin{tabular}{|l|l|l|}
\hline $\begin{array}{l}\text { Physical characteristics: } \\
\text { - activity } \\
\text { - energy }\end{array}$ & $\begin{array}{l}\text { Personal characteristics: } \\
\text { - creativity } \\
\text { - originality }\end{array}$ & $\begin{array}{l}\text { Social features: } \\
\text { - cooperation } \\
\text { - prestige }\end{array}$ \\
\hline $\begin{array}{l}\text { Social features - } \\
\text { background: } \\
\text { - mobility }\end{array}$ & $\begin{array}{l}\text { Operating characteristics: } \\
\text { - responsibility } \\
\text { - Orientation to the task }\end{array}$ & $\begin{array}{l}\text { Interpersonal skills: } \\
\text { - participation } \\
\text { - tact }\end{array}$ \\
\hline $\begin{array}{l}\text { Intelligence and ability: } \\
\text { - making conclusions } \\
\text { - determination } \\
\text { - knowledge } \\
\text { - oratory skills }\end{array}$ & & \\
\hline
\end{tabular}

In modern business conditions, leadership was studied by more than one author, starting from the contingency approach developed by Fidler, Hershey-Blanchard and the path-goal model developed by Evans and Haus. Haus also developed the model of charismatic leadership. 
Three-dimensional leaders with "full-range leadership" reflect the essence of the transformational leadership profile in which capabilities to preserve the "complex structure" and make necessary changes are expressed to the maximum.

Figure 1 shows the key attributes of the transformational leadership (Nikezić, 2011, p.82).

Nowadays, international competition is on the increase as well as the importance of strategic positioning of leaders.
1. Creativity
2. Team orientation
3. Respect
4. Educating
5. Responsibility
6. Recognition

Figure 1 - Key attributes of leaders

Puс. 1 - Ключевые качества лидеров Slika 1 - Ključni atributi lidera

In our case, 247 citizens of the Republic of Serbia (125 males and 122 females), aged 18 to 65, were interviewed through the Web research service in the period from 01.02.2014 to 07.02.2014. The survey aimed at the elimination of shortcomings in the functioning of these entities (winter service, the MIA, the Army and HQs at all levels) and the contribution of leaders from the state level to achieve better results. Comparing our results with the results of other published studies given above (without taking into account how representative the samples of these studies are), we concluded that the ability to communicate is one of the most important features of our leaders, because without the ability to communicate there is no charisma nor transfer of their vision to their followers and the others. This also applies to their ability to connect the system with communications, both vertically and horizontally, in various stages of implementing quality measures in emergency and other situations (e.g.: blizzard in Voivodina, floods in Obrenovac, etc.). roles:

In applying the concept of quality, there are three relevant leadership

1) Diagnosis, which identifies the current situation, perceives future conditions through selecting strategic actions and makes a scenario for preventive actions in emergency situations. The ability of leaders is to establish a functional link between the work oganisation of headquarters for emergency situations and the environment, to identify threats and opportunities, i.e.to anticipate and define trends in the environment which are new to headquarters as a necessity for strengthening their own position and achieving leadership through quality. 
2) Adapting also means redesigning the HQs organizational structures, a higher technological level and a combination of other relevant factors, starting with the leadership capacities based on multinational and multicultural knowledge, skills, power and influence.

3) Communication involves transmission of vision, ideas and mission, attitudes and values in a clear, concise, compelling and concrete way. This leadership role is based on educational and charismatic skills to establish and maintain interpersonal relations and affection of followers, their respect and willingness to offer support. The concept of quality is based on the mutual interaction of all the functional parts of the structure that connect specialized teams-headquarters that address various aspects of quality in the stages of preparation, planning and implementation.

There are some questions:

1. What is the role and responsibility of leaders in the relation of the mankind towards nature and natural disasters?

2. Is it important for leaders to have a proper attitude towards nature and natural disasters, i.e. to have environmental awareness and responsibility?

These questions are answered through an analysis of the event of a heuristically conceived problem (Fig. 4) in the territory of responsibility and beyond, ie. the territory of the Republic of Serbia. The problem is illustrated with the photos of various events in peace and emergencies, diagrams and the analysis and comparison of our results with the results of other researchers (Fig. 2: a, b, c, d).

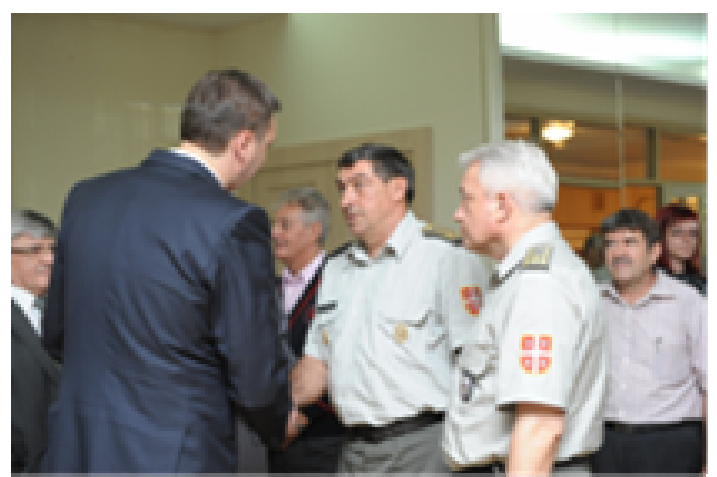

Figure 2a - The state support of scientific research work for the 60th anniversary of the Military Technical Courier (http://www.vtg.mod.gov.rs/60godina-fotogalerija-2.html)

Puc. 2a - Государственная поддержка научно-исследовательской работе, приуроченная 60-ти летию журнала „Военно-технический вестник“ (http://www.vtg.mod.gov.rs/60godina-fotogalerija-2.html)

Slika 2a - Podrška države naučnoistraživačkom radu povodom 60. godišnjice Vojnotehničkog glasnika (http://www.vtg.mod.gov.rs/60godina-fotogalerija-2.html)

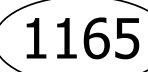




\section{Leadership in the Civil Defense}

In this region, leaders still do not pay enough attention to this topic, as evidenced by opinion polls and recent developments of emergencies such as storm winds and snow drifts, as well as the recent floods in the Republic of Serbia.

\section{Country and Leadership}

Without the impact and contribution of leadership of the country, personal example, the development of the system of defense and the support to scientific research in this field, the efforts of other members of society may be negligible, and the results of their work can be reduced and brought down to a local character from case to case, if the state does not encourage leaders at all levels by giving its support to scientific research, by raising environmental awareness and responsibility, and by reacting in emergency situations - disasters. The examples are as follows: marking the 60th anniversary of the Military Technical Courier, snow drifts in Banat and Backa, floods in Obrenovac, etc., where the state showed what the action should be in such situations (Fig. 2: a, b, c, d).

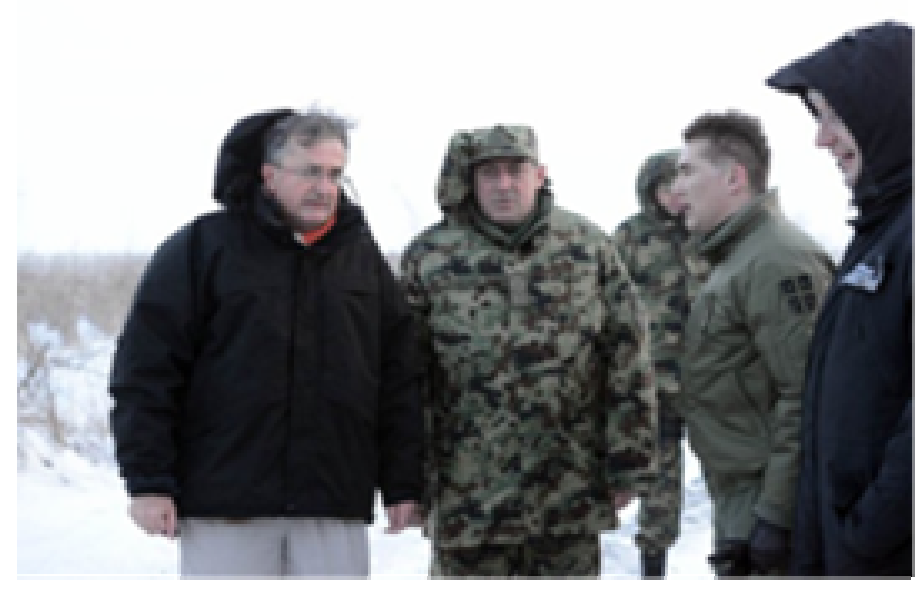

Figure $2 b-$ Government support in emergency situations (snow drifts in Banat and Backa)

Puc. 26 - Государственная поддержка в чрезвычайных ситуациях (сильная метель в Банате и Бачкой)

Slika $2 b$ - Podrška države u vanrednim situacijama (olujni smetovi u Banatu i Bačkoj) 


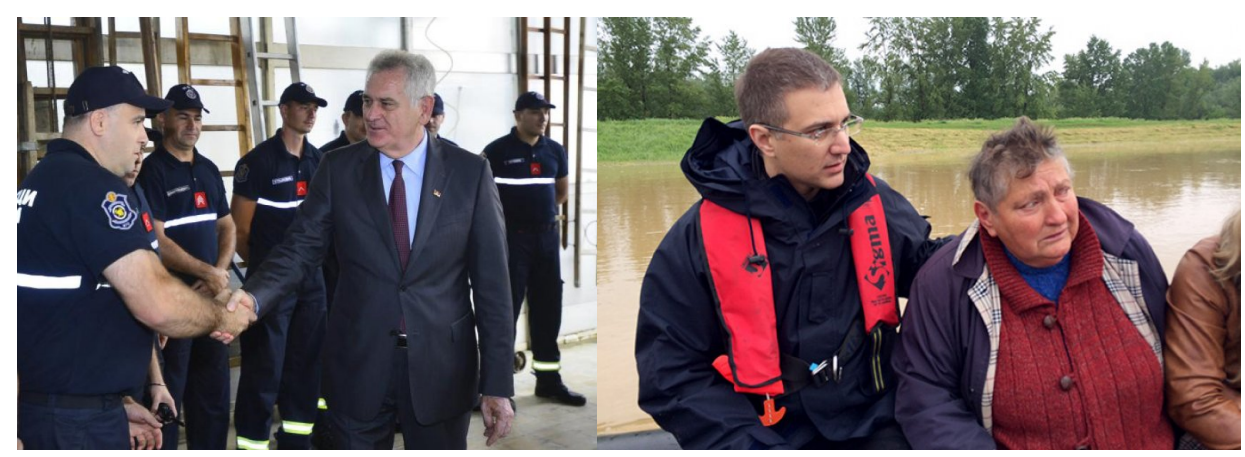

Figure 2c-Government support in emergency situations (floods in Obrenovac) Puc. 28 - Государственная поддержка в чрезвычайных ситуациях (наводнение в г. Обреновац)

Slika 2c-Podrška države u vanrednim situacijama (poplava u Obrenovcu)

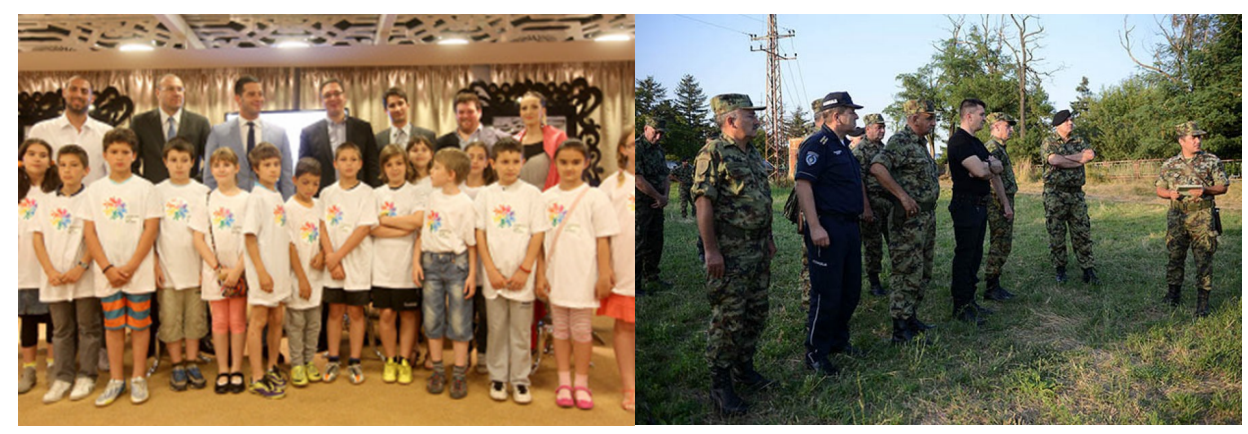

Figure $2 d$ - Support of the Government in all other situations Puc. 22 - Государственная поддержка в других ситуациях Slika $2 d$ - Podrška države u svim drugim situacijama

\section{Heuristics in emergencies and leadership}

A "heuristic approach to solving problems" (Kvaščev, 1978) and heuristic modeling mean the creation of such a heuristic model that represents more originals in one same model, ie. a model that enables acquiring new knowledge and developing creativity by putting emphasis on independence and previous knowledge in specific areas (for example, frequent emergencies (Bereš, Bereš, 2014, pp.155-159).

The heuristic model determines very little action in the course of solving problems, so it leaves team members of emergency situation HQs a possibility to find one or all possible solutions, depending on their prior knowledge, level of independence and creative capabilities. This 
approach to problem solving allows each individual - member of an $\mathrm{HQ}$ for emergency situations to reach his/her peak, no matter how talented he/she may be. The heuristic strategy means that a team member is placed in a position to find out, using prrevious experiences in new situations, new ways of creative problem solving (Bereš, 2013, pp.46-57).

Putting such a model in the function of leadership, new quality in the training is achieved. Also, a multi-media lecture with teaching topics and units is conceived as a heuristic algorithm (Figure 3), which allows listeners to select unknown matter and skip the already known, so that they achieve their maximum individuality at work.

This heuristic model as a function of leadership at all levels allows listeners a better understanding of leadership in emergency and all other situations (Figures 2 a, b and c, Figure 3 and Table 3 ).

\section{Problem solving and adequate decision-making}

The problem discussed is one of emergency situations (Figure 3) that can occur in Europe, Serbia or the Central Banat region, ie. blizzard with snow drifts, on the one hand, and the impact and contribution of the leadership of the country, on the other hand.

The problem is heuristically designed and described by quantitative methods to show the status or cause-effect relationships among phenomena in each of possible emergencies.

Various emergency situations in Serbia and Montenegro (19892006) given in the Final Report on the Risks in the Countries of South Eastern Europe - Sout Eastern Europe Disaster Risk Management Initiative - SEEDRMI, July 2007) have the following potential risks (Bereš et al., 2015, p.71, see Figure 1):

- Natural risks: - Dangerous meteorological phenomena: floods 34\%, blizzards-snow drifts $4 \%$, high temperatures - drought and forest fires $12 \%$, strong frosts - other $4 \%$, destructive geological phenomena: landslides, earthquakes $4 \%$.

- Biological risks: epidemics, animal epidemics, zoonoses $8 \%$.

- Technological risks: industrial accidents $8 \%$, transport and storage of hazardous products, mass fires and explosions, road and rail transport, waterways, airways $26 \%$, water pollution, potential contamination, demolition of buildings or installations, accidents caused by a cancellation of public services, objects falling from the atmosphere or the outerspace, unexploded ammunition $4 \%$ - in total 36 risks, i.e. emergencies which may happen in the European region of Banat (Bereš, 2013, pp.46-57). 


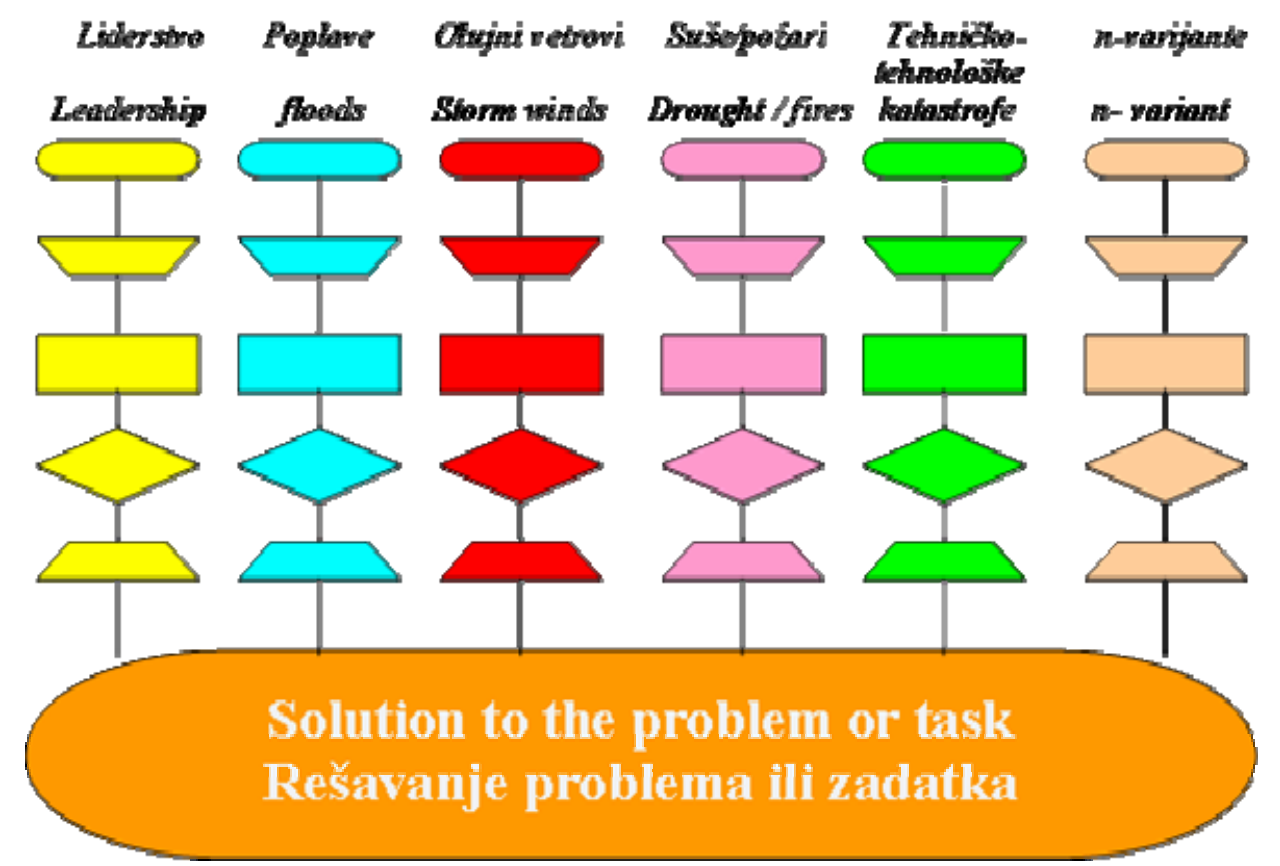

Figure 3 - Problem situation - heuristic algorithm (Amaldi, et al, 2003)

Puc. 3 - Проблемная ситуация - Эвристический алгоритм (Amaldi, et al, 2003)

Slika 3 - Problemska situacija - heuristički algoritam (Amaldi, et al, 2003)

\section{Education-problem solving-decision making}

All units engaged in the protection and rescue, receive assignments from the Headquarters for Emergency Situations in whose territory the emergency, or, if necessary, the state of emergency was declared. The actions of particular entities, from the local to the national level, were rated in an anonymous questionnaire (Table 3; actions from 1 to 6). 247 citizens of the Republic of Serbia (125 males and 122 females), aged 18 to 65 , were interviewed through a Web research service in the period from 01.02.2014 to 07.02.2014. The survey was aimed at the elimination of shortcomings in the functioning of these entities (winter services, MIA, the Army and HQs at all levels) and the contribution of the state leaders to achieve better results in problem solving. 
Table 3 - Public opinion on the actions of the Civil Defence entities Таблица 3 - Мнение граждан о мероприятиях представителей Гражданской обороны Tabela 3 - Mišljenje građana o postupanju subjekata civilne odbrane

\begin{tabular}{|l|c|c|c|}
\hline Actions / evaluation & Positive & Negative & No opinion \\
\hline \hline Winter services & 58.3 & 39.67 & 02.03 \\
\hline \hline Gendarmerie & 78.14 & 18.62 & 03.24 \\
\hline \hline The Army of Serbia & 88.67 & 08.09 & 03.24 \\
\hline \hline Government of Serbia & 44.65 & 47.20 & 08.15 \\
\hline \hline $\begin{array}{l}\text { Headquarters for } \\
\text { Emergency Situations }\end{array}$ & 44.35 & 47.53 & 8.12 \\
\hline \hline Prime Minister of Serbia & 60.72 & 31.18 & 18.10 \\
\hline
\end{tabular}
levels.

Based on the problem solution, adequate decisions are made at all

The survey was conducted via the Web research service, "Your attitude," and its analysis aims at answering the questions, "How do you rate the actions of: 1. winter services, 2 MIA - Department for Emergency Situations, 3. Ministry of Defense and the Army Serbia, 4. Headquarters for emergency situations at all levels, and 5. Prime Minister of the Republic of Serbia (at that time the First Vice-President), in assisting the elimination of the identified deficiencies in the functioning of these entities (winter services, the MIA, the Army and the HQs at all levels).

The survey results (Table 3 ) clearly show that a large percentage of the Ministry of Defense and the Army of Serbia met the expectations of the citizens of the AP of Voivodina and the Republic of Serbia. In the second place was the MIA of Serbia, and the winter services in the third. Since the headquarters for emergency situations at all levels were in the fourth place, it can be concluded that, in the opinion of citizens, they did not perform well so they are suggested to practice more through exercises.

In the experiment, the analysis of the events on the ground and heuristics helped to identify and define the problem, i.e. to determine a set of alternative solutions and a set of criteria for evaluating alternatives in order to select them and make appropriate decisions. The implementation of selected alternatives is monitored and the results achieved are evaluated in order to determine whether a solution to the problem is satisfactory from the point of view of a leader as a factor of good leadership transferred from the state level, ie. national level to the local level.

Satisfactory solutions to problems serve as an example in further education of headquarters for emergency situations and preventive 
planning in the system of civil defense, especially regarding leadership (Figs. 2: $a, b, c)$ qualities of $\mathrm{HQ}$ commanders at all levels through the already presented heuristically conceived problem (Figure 3).

\section{Conclusion}

The main characteristic of good leaders is that they have great power which is not based on force but on spreading clear ideas - this makes them a key factor in the functioning of the system of civil defense in emergencies and after the declaration of a state of emergency as well as in everyday life (Figs. 2 a,b,c). The aim is to educate HQ members to rationally use existing resources through team work on joint projects that combine different ideas of team members. All subjects from local levels should be engaged in order to manage emergency situations (floods, stormy winds with snow drifts, droughts, fires, technological disasters, etc.), and these models should find their place in emergencies through a demonstration of their application on concrete examples with the aim of making timely rational decisions in preventive actions and eliminating the consequences of possible disasters.

The leaders in this study obtain the support of their followers thanks to clear ideas in which many members of the society recognize their own interests with ease, and accept them with faith, understanding and enthusiasm in their implementation.

When these ideas are positive, such as the idea of improving the attitude towards the environment, (Klemenović, 2007, p.379) natural and civilization disasters, leaders realize their mission which benefits the society.

At present turbulent times of globalization and multinational and multicultural linking, the organization of headquarters for emergency situations must be continually adapted, developed and innovated. Leadership should not be viewed only from the perspective of local authorities and economic organizations, but also at the national level. A country, i.e. a wider community with a leader committed to the idea of development, contributes to its implementation at the state level. Leadership is important and is a key factor to improving the overall quality of the whole society.

\section{References}

Ajduković, G. 2007. Lideri i liderstvo viđeni očima ljudi iz Srbije. In: Zbornik radova: Liderstvo u zemljama tranzicije, FTB.Beograd., pp.17-24.

Amaldi, E., Capone, A., \& Malucelli, F., 2003, Optimization models with power control and algorithm. Retrieved from: https://www.google.rs/?gws_rd=cr\&ei=kz BUvvEAsWatQbT4YGwBw\#q=planning+umts+base+station+location+optimization+mode Is+with+power+control+and+algorithms 
Bennis, W.G. 2003. On becoming a leader: The leadership classic: Updated and expanded.USA: Perseus Publishing.

Bereš, P., Bereš, K., Cvetković S. \& Jazić R. 2015. Istorijska analiza i heuristika u funkciji edukacije štabova za vanredne situacije / Historical analisys and heuristics as a function of emergency team education: Experience of the CMoD Zrenjanin. Vojnotehnički glasnik / Military Technical Courier, 63(1), pp.67-83.

Bereš, P., \& Bereš, K. 2014. Heuristika i operaciona istraživanja u funkciji edukacije subjekata sistema civilne odbrane za vanredne situacije / Heuristics and operational research in emergency situations and civil defence education. Vojnotehnički glasnik / Military Technical Courier, 62(3), pp.152-164.

Bereš, P., 2013, Heuristički model edukacije i prototip sistema za daljinsko aktiviranje sirena u vanrednim situacijama / Heuristic model of education and a prototype of a system for remote siren activation in emergency, Vojnotehnički glasnik / Military Technical Courier, 61(1), pp.46-57.

Hotomski, P.1995. Sistemi veštačke inteligencije.Zrenjanin: Tehnički Fakultet, "Mihajlo Pupin".

Kirkpatrick, S.A., \& Locke, E.A. 2001. Leadership: Do traits matter. Academy of Management Executive, 5, pp.48-60.

Klemenović, J. 2007. Filozofsko-etičko utemeljenje ekološkog vaspitanja i obrazovanja - drugi deo. Pedagogija, 3(7), pp.374-384. LXII.

Kvaščev, R. 1978. Modeli procesa učenja.Beograd: Prosveta.

Luthans, F. 2005. Organizational Behaviour.Boston: McGraw Hill.

Nikezić, S. 2011. Organizacija i okruženje.Satcip: Vrnjačka Banja.

Retrived from: http://www.vtg.mod.gov.rs/60godina-fotogalerija-2.html

РОЛЬ ГРАЖДАНСКОЙ ОБОРОНЫ, ЛИДЕРСТВА И ЭВРИСТИКИ В ПОДГОТОВКЕ ШТАБОВ ЧРЕЗВЫЧАЙНЫХ СИТУАЦИЙ

Паун Й. Береш ${ }^{a}$, Кристиан П. Береш ${ }^{б}$, Сретен С. Цветкович ${ }^{a}$

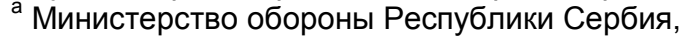

Управление по обязательствам обороны, Региональный центр г. Нови Сад,

Центр МО Зренянин, Республика Сербия

${ }^{\sigma}$ Intelliview AS, г. Осло, Норвегия

ОБЛАСТЬ: подготовка

ВИД СТАТЬИ: профессиональная статья

ЯЗЫК СТАТЬИ: английский

\section{Резюме:}

В данной статье представлено решение проблем Гражданской обороны эвристическим методом, способствующим принятию соответствующих решений в чрезвычайных ситуациях и при чрезвычайном положении, с особым акцентом на применение эвристической модели в подготовке штабных команд по чрезвычайным ситуациям, а также роли лидера, как положительного фактора лидерства. Данная модель предназначена командному и преподавательскому составу кадров 
Гражданской обороны: местному самоуправлению (начальникам районных управлений, председателям районных Советов, мэрам, председателям муниципальных округов и командирам), а также аварийно-спасательным службам (Сектор по чрезвычайным ситуациям). Эвристический метод решения проблем способствовует правильному выбору решений командного персонала, при наступлении чрезвычайных обстоятельств и объявлении чрезвычайного положения, как на местном, так и на национальном уровне Республики Сербия, а также функционированию систем Гражданской обороны и третьей миссии Вооруженных сил Республики Сербия, указывая на необходимость координации региональных и национальных уровней системы.

Ключевые слова: гражданская оборона, лидерство, эвристика.

\section{CIVILNA ODBRANA, LIDERSTVO I HEURISTIKA U FUNKCIJI EDUKACIJE ŠTABOVA ZA VANREDNE SITUACIJE}

Paun J. Bereša ${ }^{a}$ Kristian P. Bereš ${ }^{b}$, Sreten S. Cvetković ${ }^{a}$

${ }^{a}$ Ministarstvo odbrane Republike Srbije, Uprava za obaveze odbrane,

Regionalni centar Novi Sad, Centar MO Zrenjanin, Republika Srbija

${ }^{\mathrm{b}}$ Intelliview AS, Oslo, Norveška

OBLAST: edukacija

VRSTA ČLANKA: stručni članak

JEZIK ČLANKA: engleski

\section{Sažetak:}

U članku je prezentirano rešavanje heuristički koncipiranih problema civilne odbrane, donošenjem adekvatnih odluka $u$ vanrednim situacijama $i$ vanrednom stanju, sa posebnim osvrtom na primeni heurističkog modela edukacije timova -štabova za vanredne situacije i uloge lidera kao faktora dobrog liderstva. Rad je namenjen komandnom i nastavnom kadru civilne odbrane: lokalnim samoupravama (načelnicima upravnih okruga, gradonačelnicima i predsednicima opština - komandantima) i sistemu zaštite $i$ spasavanja (Sektoru za vanredne situacije). Heuristički pristup rešavanju problema treba da omogući komandnom kadru - liderima od lokalnog do nacionalnog nivoa, donošenje adekvatnih odluka u vanrednim situacijama po proglašenju vanredne situacije $i$ vanrednog stanja na delu teritorije ili celoj teritoriji Republike Srbije.Takođe, treba da stvori uslove za funkcionisanje sistema civilne odbrane i treće misije Vojske Srbije, kao i da ukaže na neophodnost koordinacije između lokalnog i nacionalnog nivoa.

Ključne reči: civilna odbrana, liderstvo, heuristika. 
Paper received on / Дата получения работы / Datum prijema članka: 17. 08. 2015. Manuscript corrections submitted on / Дата получения исправленной версии работы / Datum dostavljanja ispravki rukopisa: 30. 06. 2016.

Paper accepted for publishing on / Дата окончательного согласования работы / Datum konačnog prihvatanja članka za objavljivanje: 01. 07. 2016.

(c) 2016 The Authors. Published by Vojnotehnički glasnik / Military Technical Courier

(www.vtg.mod.gov.rs, Втг.мо.упр.срб). This article is an open access article distributed under the terms and conditions of the Creative Commons Attribution license (http://creativecommons.org/licenses/by/3.0/rs/).

() 2016 Авторы. Опубликовано в "Военно-технический вестник / Vojnotehnički glasnik / Military Technical Courier" (www.vtg.mod.gov.rs, втг.мо.упр.срб). Данная статья в открытом доступе и распространяется в соответствии с лицензией "Creative Commons"

(http://creativecommons.org/licenses/by/3.0/rs/).

(C) 2016 Autori. Objavio Vojnotehnički glasnik / Military Technical Courier (www.vtg.mod.gov.rs, втг.мо.упр.срб). Ovo je članak otvorenog pristupa i distribuira se u skladu sa Creative Commons licencom (http://creativecommons.org/licenses/by/3.0/rs/).

(c) (i) 